\title{
Measuring the Effects of Environmental Regulation in Oligopolistic Markets with Differentiated Products
}

Claudio Ferraz, Eduardo P S Fiuza and Ronaldo Serôa da Motta

Working Paper No 36

May 2001

International Institute for Environment and Development, London, and Institute for Environmental Studies, Amsterdam 


\section{Authors}

Claudio Ferraz and Eduardo Fiuza are researchers at the Institute for Applied Economics Research (IPEA). Ronaldo Serôa da Motta is Coordinator of Environmental Studies at IPEA and Professor at the Universidade Santa Ursula, Brazil. They can be reached at:

Instituto de Pesquisa Econômica Aplicada (IPEA)

Av. Presidente Antonio Carlos 51, 17o andar, Rio de Janeiro, R.J. 20020-010

E-mail:cferraz@ipea.gov.br. 
The programme of Collaborative Research in the Economics of Environment and Development (CREED) was established in 1993 as a joint initiative of the International Institute for Environment and Development (IIED), London, and the Institute for Environmental Studies (IVM), Amsterdam. The Secretariat for CREED is based at IIED in London. A Steering Committee is responsible for overall management and coordination of the CREED Programme.

\section{Environmental Economics Programme, IIED}

IIED is an independent, non-profit organisation which seeks to promote sustainable patterns of world development through research, training, policy studies, consensus building and public information. The Environmental Economics Programme is one of seven major programmes of IIED; it conducts economic research and policy analysis for improved management of natural resources and sustainable economic growth in the South.

Environmental Economics Programme

IIED, 3 Endsleigh Street

London WC1H 0DD, UK

Tel +44 (0)20 7388 2117; Fax +44 (0)20 73882826

e-mail: frances.reynolds@iied.org

\section{Institute for Environmental Studies, (IVM)}

IVM is a non-profit research institute, based at Vrije Universiteit, Amsterdam. The Institute's primary objective is to carry out multi- and interdisciplinary research on environmental issues, based on crossfertilisation of monodisciplinary sciences. Environment and the Third World is one of eight major IVM research programmes.

IVM, Vrije Universiteit

De Boelelaan 1115

1081 HV Amsterdam

The Netherlands

Tel: +31 20444 9555; Fax: +31204449553

e-mail:secr@ivm.vu.nl

\section{CREED Steering Committee members include:}

Prof Johannes Opschoor, Institute for Social Studies, The Netherlands (Chair)

Prof Gopal Kadekodi, Centre for Multidisciplinary Development Research, India

Dr Ronaldo Seroa da Motta, IPEA, Brazil

Dr Mohamud Jama, Institute for Development Studies, Kenya

Dr Anantha K. Duraiappah, IVM, The Netherlands

Prof Harmen Verbruggen, IVM, The Netherlands

Joshua Bishop, IIED, UK

Maryanne Grieg-Gran, IIED, UK

Abstracts of CREED publications and details of all CREED projects

are now available on the Internet. Visit the CREED website at: 


\section{Acknowledgements}

This paper comes from the project "Effects of vehicle characteristic taxes on pollution control in Brazil and Costa Rica". Financial support from the Dutch Ministy of Foreign Affairs under the Collaborative Research on the Economics of Environment and Development (CREED) programme is gratefully acknowledged. The authors also wish to thank Cicero Pimenteira, Alexia Rodrigues and Roberta Neiva for valuable research assistance, and Nick Johnstone for helpful discussions. 


\begin{abstract}
Pollution emissions from vehicles have increased considerably in recent years in many Brazilian cities, causing significant health problems. As a response, environmental standards for automobile pollution were implemented in 1988, and considerable reductions in emissions were attained. Nevertheless, in 1997 substantial differences in emissions between car models still remained, suggesting the need for further regulation. This paper simulates the effects of a new environmental standard on the automobile market. Using a discrete-choice model of demand and disaggregated data on the Brazilian car market from 1993 to 1997, we estimate own- and cross-price elasticities for each car model. This estimation is undertaken using a nested-logit model taking into consideration the choice between car classes and nationality. An oligopoly framework with differentiated products is used in the supply side in order to estimate unobserved marginal costs. In addition a hedonic-cost function relating marginal cost to characteristics and emissions is estimated. Based on the results obtained and the 1997 emissions data, a counterfactual simulation of a new pollution standard for hydrocarbon vehicle emissions is undertaken. The results indicate that, given the existing technology, imposing a new standard of 0.15 grammes per kilometre for all automobiles would lead to an average price increase of $12 \%$ and a reduction in total sales of $31 \%$. This would generate a $39 \%$ reduction in total $\mathrm{HC}$ emissions per kilometre driven, with a tax revenue loss of $16 \%$. The paper concludes that, although substantial emissions reductions could be induced by a tighter standard, the welfare effects of such a policy requires further analysis.
\end{abstract}

\title{
Abrégé
}

Ces dernières années, les émissions polluantes des véhicules automobiles ont connu une forte augmentation dans de nombreuses agglomérations brésiliennes, engendrant de sérieux problèmes de santé. Pour y faire face, des normes environnementales ont été appliquées à la pollution automobile en 1988, qui ont permis d'obtenir des réductions considérables de ces émissions. Il subsistait cependant, en 1997, des différences substantielles d'émission selon les modèles de voiture, indice d'un nécessaire surcroît de réglementation. Ce travail propose une simulation des effets qu'aurait sur le marché de l'automobile une nouvelle norme environnementale. Mettant en œuvre un modèle à choix discret de la demande et des données fragmentées relatives au marché automobile brésilien de 1993 à 1997, nous estimons, pour chaque modèle de voiture, son élasticité-prix intrinsèque et croisée. Cette estimation est obtenue à l'aide d'un modèle logistique (logit) emboîté prenant en considération le choix entre classes et origines nationales des voitures. En ce qui concerne l'offre, on utilise un cadre d'oligopole à produits différenciés afin d'estimer les coûts marginaux ayant échappés à l'observation. Par ailleurs, on évalue une fonction de coût hédonistique établissant la relation entre le coût marginal et les caractéristiques et émissions des véhicules. On réalise ensuite, à partir des résultats ainsi obtenus et des données d'émission relevées en 1997, une simulation contrefactuelle des effets d'une nouvelle norme antipollution appliquée aux émissions d'hydrocarbures par les véhicules. Ces résultats indiquent qu'au vu de la technologie existante, l'imposition d'une nouvelle norme établie à 0,15 grammes au kilomètre pour toutes les automobiles aboutirait à une augmentation moyenne de leur prix de $12 \%$ et à une chute de $31 \%$ des ventes totales. Elle provoquerait une réduction de $39 \%$ des émissions totales d'hydrocarbure par kilomètre parcouru, avec une baisse de $16 \%$ des rentrées fiscales. Le texte arrive à la conclusion que bien que des réductions sustantielles des émissions polluantes puissent être obtenues grâce à une norme plus stricte, les effets d'une telle politique sur le bien public ont besoin d'être analysés plus à fond.

\section{Resumen}

Las emisiones vehiculares han aumentado considerablemente en años recientes en muchas ciudades del Brasil, causando graves problemas de salud. En respuesta a esto, en 1988 se creó una serie de normas de control de contaminación vehicular, lo cual redujo las emisiones significativamente. Sin embargo, hacia 1997, todavía existían diferencias sustanciales entre los diversos modelos de vehículos, lo que lleva a pensar en la necesidad de nuevas medidas regulatorias. Este artículo simula los efectos de una nueva norma en el mercado automotor. Con este propósito, se utilizaron un modelo de demanda de opciones discretas y datos desagregados del mercado automotor en el Brasil entre 1993 y 1997 y así se calcularon la elasticidad propias y relativas de todos los precios para cada modelo automotor. Este cálculo se realizó utilizando un modelo nested-logit teniendo en cuenta la opción entre tipos de automóviles y nacionalidades. Con el objeto de calcular los costos marginales no observables se empleó un marco oligopólico de oferta con productos diferenciados. También se utilizó una función de costos hedónicos relacionando los costos marginales con las características y las emisiones. Con base en los resultados de esta función y mediante la utilización de los datos de emisiones recogidos en 1997, se realizó una simulación contrafactual de nuevas normas de contaminación para emisiones de hidrógeno de carbono. Los resultados indican que, dada la tecnología existente, la imposición de una nueva norma de 0.15 gramos por kilómetro para todos los automóviles, conduciría a un aumento en los precios de $12 \%$ y a una reducción en el total de ventas de $31 \%$. Esta medida generaría una reducción de $39 \%$ en el total de emisiones de hidrógeno de carbono por kilómetro recorrido, con una pérdida fiscal de $16 \%$. La conclusión a la cual se llega en este artículo es la de que a pesar de que es posible reducir considerablemente las emisiones mediante normas más severas, los efectos sobre el bienestar de la población requieren un examen más detallado. 


\section{Contents}

$\begin{array}{ll}\text { Introduction } & 1\end{array}$

The Model $\quad 3$

The demand side $\quad 3$

The supply side $\quad 4$

Econometric Issues $\quad 6$

Data and Econometric Results 8

Data 8

Results for the estimated nested-logit model 9

Results for the estimated hedonic marginal cost 11

Simulating the Effect of Environmental Regulation 13

The effects of a new environmental standard 14

$\begin{array}{ll}\text { Concluding Remarks } & 17\end{array}$

$\begin{array}{ll}\text { Bibliography } & 19\end{array}$ 


\section{Introduction}

The number of cars circulating in Brazil increased from 9,527,296 units in 1985 to approximately 16,247,643 units in 1998 with ownership highly concentrated in the richest and most urbanised regions. ${ }^{1}$ Traffic jams have become a common feature of cities like Rio de Janeiro and São Paulo, and pollution emissions have caused considerable deterioration in the air quality. Emissions from vehicles are the major source of air pollution in Brazil's largest cities. In São Paulo, for example, private cars were responsible for approximately $75 \%$ of carbon monoxide (CO), $73 \%$ of hydrocarbons (HC), $23 \%$ of nitrogen oxides (NOx) and 10\% of particulate matter (PM) emissions in 1997 (Cetesb, 1998). ${ }^{2}$ Costs associated with severe air pollution concentrations in large cities are significant. The cost in human health is also significant, with symptoms ranging from eye irritation to respiratory problems and increasing cancer rates, all of which incur direct and indirect costs to society. ${ }^{3}$

In order to address the problem of vehicle emissions, a national emissions control programme was introduced in 1988. The Vehicle Air Pollution Control Programme (Proconve) established compulsory inspections for new vehicles entering the market and a gradual adjustment schedule with emissions standards set for 1992 and 1997. ${ }^{4}$ The automobile industry used catalytic converters and multi-point fuel injections to comply with standards, and the programme resulted in substantial emissions reductions for all car categories. ${ }^{5}$ Nevertheless, considerable differences in emissions still remained among car models in 1997, especially between national and imported cars, suggesting the need for further regulation. This paper aims at quantifying the effects of a new environmental regulation on prices, car sales, tax revenues and pollution emissions measured by Hydrocarbons (HC).

In a competitive market, cost increases induced by government regulation are passed on to the consumer, and a new equilibrium arises with lower sales. However, in an oligopolistic context with differentiated products, the strategic behaviour of firms might generate different effects on pollution and tax revenue. The simulation of government policies in oligopolistic markets is carried out in Berry, Levinsohn and Pakes (1998), Fershtman, Gandal and Markovitch (1999) and Goldberg (1998). They all find the use of differentiated product models significant in the analysis of the effects of government policies in oligopolistic markets.

Our objective is to simulate the effects of stringent environmental regulation in the Brazilian car market. In order to simulate environmental policies, automobile demand and supply parameters are needed. Building on recent advances in the theory of demand for differentiated products (Berry, 1994; Berry, Levinsohn and Pakes, 1995; Goldberg, 1995; and Verboven, 1996), we merge aggregate data from the automobile market with pollution emissions data

\footnotetext{
${ }^{1}$ See Anfavea (1998) for a description of the automobile market.

${ }^{2}$ According to Cetesb (1998), the air quality in the São Paulo metropolitan area is considered to be below the human health minimum standard for at least $25 \%$ of days in a year.

${ }^{3}$ See Serôa da Motta and Mendes (1995). See also Small and Kazimi (1995) for further analysis of social costs associated with vehicle-source air pollution.

${ }^{4}$ See Ferraz and Serôa da Motta (2000) for an analysis of the pattern of adjustment that took place in the automobile industry.

${ }^{5}$ Cetesb (1999) estimates reductions of $96 \%$ in $\mathrm{CO}, 94 \%$ in $\mathrm{HC}$ and $86 \%$ in NOx emission rates for the $1985-$ 1998 period.
} 
obtained from tests carried out by the São Paulo state environmental agency (Cetesb), from 1993 to 1997, to estimate demand elasticities and mark-ups in differentiated product markets.

A nested-logit demand model similar to that used in Goldberg and Verboven (1998) is used to estimate elasticity parameters while the supply side of the oligopolistic model is used to estimate mark-ups and marginal costs for each car model. In order to analyse the effect of pollution control on marginal costs, a hedonic-cost function similar to that used in Berry, Levinsohn and Pakes (1995), relating estimated marginal cost to automobile characteristics (including pollution emissions), is estimated, and the parameter relating emissions to marginal cost is used for simulation purposes. ${ }^{6}$

The exercise is important because of the need to analyse the effect of environmental policies in oligopolistic markets. Although there is a growing body of literature which analyses the possibilities of using different instruments for controlling car pollution, (Eskeland, 1994; Innes, 1996; Johnstone and Karousakis, 1998; Sevigny, 1998; Fullerton and West, 2000), none of the papers introduce the fact that car markets are characterised by differentiated product oligopolies. However, unlike the previously cited papers, this paper does not analyse optimal schemes for reducing emissions. Our objective is to analyse the effects of government regulation on the composition of new car sales, and consequently, on emissions and tax revenues.

The exercise that we undertake is closely related to research carried out by Pakes, Berry and Levinsohn (1993); Berry, Levinsohn and Pakes (1998); Goldberg (1998), and Fershtman et al (1999). Given the estimated parameters and the demand and pricing equations, we introduce an additional marginal cost to achieve stricter car emissions levels. Total emissions between the new situation and the baseline are then compared and the environmental gains in the new fleet composition are assessed. Additionally, we are able to compute new prices, sales and tax revenues and the costs to society to reduce emissions are outlined.

The paper is organised as follows. The following section describes the model. Section Three discusses econometric issues. Section Four describes the dataset and presents the results obtained from the demand and marginal costs estimations. Section Five contains the environmental simulation, and the final section contains some concluding remarks.

\footnotetext{
${ }^{6}$ See Berry, Kortum and Pakes (1996) for the use of hedonic cost functions to analyse environmental change.
} 


\section{The Model}

We model the Brazilian car market as a multi-product oligopoly market where firms produce several differentiated products and compete in different segments. Following earlier work on differentiated product oligopoly pioneered by Berry (1994), we assume that firms compete in prices with cars that are differentiated by specific attributes. ${ }^{7}$ On the other side of the market, consumers have a random utility based on car prices and attributes.

\section{The demand side}

There are $M$ potential consumers in the automobile market who face the choice of either buying a car or buying an alternative good. We assume that consumers buy cars based on a set of observable characteristics including the price and other physical attributes such as engine size, air conditioning and other accessories, and unobserved characteristics such as the preference for a specific brand or colour. ${ }^{8}$ Although automobiles have different pollution emission levels, we assume that consumers do not take this characteristic into account when choosing a vehicle type. The conditional indirect utility obtained by consumer $i$ from buying a car $j, u_{i j}$ is assumed to be linear in product characteristics and it is expressed as,

$u_{i j}=x_{j} \beta-\alpha p_{j}+\xi_{j}+v_{i j}$

where $x_{j}$ and $\xi_{j}$ are respectively observed and unobserved car characteristics, $p_{j}$ is the car price, $\beta$ and $\alpha$ are parameters to be estimated and $v i j$ is the mean-zero stochastic term, which represents the distribution of consumer preferences around the mean. Automobile characteristics and prices for a specific car model are common to all consumers, but the stochastic term $v$ is specific for each individual.

The shape of the demand function as well as the substitution pattern that emerges from the model is directly related to the distribution assumed for the stochastic term $v_{i j}$. We follow previous applications of the nested-logit model to the automobile industry and assume a bilevel nested-logit model similar to Verboven (1996) and Goldberg and Verboven (1998). The set of car models available are divided in $G+1$ groups where group 0 is composed uniquely of the sub-group's alternative good. Each group $g=1, \ldots, G$ is further divided in $H_{g}, h=1, \ldots, H_{g}$. We assume that consumers' choice is nested within groups and sub-groups. The first nest imposes the choice of car class (popular, compact, medium, large and luxury) and the second nest imposes the choice of nationality, i.e. foreign and domestic cars. ${ }^{9}$

The specific part of the utility function $v_{i j}$, can be decomposed as,

\footnotetext{
7 The estimation of the impact of government policy reforms using a perfect competition approach could generate substantial bias on the results, as showed by Fershtman et al (1999) for the case of Israel.

${ }^{8}$ This presentation of the model follows Verboven (1996).

${ }^{9}$ The class division used is based on market research and information from the market. See for example Gaseta Mercantil (1999). The appropriateness of this nesting structure for the Brazilian market can be tested based on the parameters estimated by the model.
} 


$$
\varepsilon_{i g}+\left(1-\sigma_{2}\right) \varepsilon_{i h g}+\left(1-\sigma_{1}\right) \varepsilon_{i j}
$$

where $h$ refers to a sub-group and $g$ refers to a group. The residuals are common to all products in the respective group or sub-group and the parameters $\sigma_{1}$ and $\sigma_{2}$ measure the degree of substitution of cars within a group or sub-group. We would expect cars that compete in the same group and sub-group to have a higher degree of substitution than cars that only compete in the same group. ${ }^{10}$

If $v$ is an extreme value distribution (Weibull), the market share for car $j$ in sub-group $h$ and group $g$, defined as the quantity of car $j$ sold divided by the size of the market $M$, is given by

$$
S_{j}=S_{j / h g} S_{h / g} S_{g}=\frac{e^{\delta_{j} /\left(1-\sigma_{1}\right)}}{D_{h g}} \frac{\mathrm{D}_{h g}^{\left(1-\sigma_{1}\right) /\left(1-\sigma_{2}\right)}}{\sum_{h \in \mathfrak{I}_{g}} D_{h g}^{\left(1-\sigma_{1}\right) /\left(1-\sigma_{2}\right)}} \frac{\left[\sum_{h \in \mathfrak{I}_{g}} D_{h g}^{\left(1-\sigma_{1}\right) /\left(1-\sigma_{2}\right)}\right]^{\left(1-\sigma_{2}\right)}}{\sum_{g \in \mathfrak{I}_{G}}\left[\sum_{h \in \mathfrak{I}_{g}} D_{h g}^{\left(1-\sigma_{1}\right) /\left(1-\sigma_{2}\right)}\right]^{\left(1-\sigma_{2}\right)}}
$$

where $D_{h g}=\sum_{j \in \mathfrak{I}_{h g}} e^{\delta_{j} /\left(1-\sigma_{1}\right)}$ and $\delta_{j}=x_{j} \beta-\alpha p_{j}+\xi_{j}$ is the mean utility level for consuming automobile $j$. Following Berry (1994), equation (3) can be inverted to yield the estimated demand equation:

$$
\ln \left(s_{j} / s_{0}\right)=x_{j} \beta-\alpha p_{j}+\sigma_{1} \ln \left(s_{j / h g}\right)+\sigma_{2} \ln \left(s_{h g / g}\right)+\xi_{j}
$$

where $s_{j / h g}$ is the share of product $j$ in the sub-group $h$ and $s_{h g / g}$ is the share of the sub-group $h$ on the group $g, s_{0}$ is the proportion of consumers that chose the alternative of not buying a car, and $\alpha, \beta, \sigma_{l}$ and $\sigma_{2}$ are parameters to be estimated.

\section{The supply side}

Automobiles are produced by multi-product firms selling differentiated products in an oligopolistic market. Producers are modelled as setting the prices of their products to maximise profits from all the models they sell. Each firm $f$ produces some subset $\mathfrak{J}_{f}$ of the set comprised by $j=1, \ldots, J$ different car models. The profit function of firm $f$ is given by,

$$
\sum_{j \in \mathfrak{I}_{f}}^{F}\left(p_{j}(1-\tau) /(1+t)-m c_{j}\right) s_{j}(p) M
$$

where $p_{j}$ is the retail price of car $j, t$ is the federal value-added tax rate (IPI), $\tau$ is the state-level value added tax (ICMS), $m c_{j}$ is the marginal cost of producing car $j$. The quantity of cars produced, $q_{j}$, is defined as $q_{j}=M s_{j}(p)$ where $s_{j}$ is the market-share of car $j$ and $M$ is the size of the market represented by the number of households in the Brazilian market.

\footnotetext{
${ }^{10}$ The condition that $\sigma_{2} \geq \sigma_{1}$ is needed for consistency of the nested-logit model with the random utility model. See McFadden, 1981.
} 
Maximising (5) with respect to price and assuming that a pure-strategy interior equilibrium exists, we obtain for each firm the first-order condition equating price to marginal cost plus a mark-up:

$$
\left.\underset{r \in \mathfrak{I}_{f}}{\stackrel{\rho}{\underline{\underline{p}}}} p_{r}(1-\tau) /(1+t)-m c_{r}\right) \frac{\partial s_{r}(p)}{\partial p_{j}}+s_{j}(p) \cdot(1-\tau) /(1+t)=0 .
$$

Grouping all first-order conditions for all the $J$ car models produced, we obtain a system of $J$ first-order conditions implying price-cost mark-ups for each good. These $J$ first-order conditions can be transformed into $J$ pricing equations. Following Berry, Levinsohn and Pakes (1995), we define a $J x J$ matrix whose $(j, k)$ element is $\Delta_{j k}=-\partial s_{k} / \partial p_{j}$ if $j$ and $k$ are produced by the same firm and $\Delta_{j k}=0$ otherwise. Defining the first-order condition in vector notation and inverting the delta matrix gives

$$
p=m c \cdot(1+t) /(1-\tau)+\Delta^{-1} s(p)
$$

The system of pricing equations breaks down the price of each car type into its marginal cost and mark-up. Elasticity parameters estimated from the demand side of the model and the equilibrium price vector are then used to calculate mark-ups.

Although data on the marginal cost is not available, we are able to use demand parameters, prices and market shares, along with estimated elasticities, to obtain an estimate of the marginal cost. Since prices are observed and mark-ups are explicitly calculated using $\Delta^{-1} s(p)$ we can calculate marginal cost for each car model $j$ in each year $t$. Following Berry, Levinsohn and Pakes (1995) and assuming that firms have marginal cost functions that are log-linear in character, we can express marginal cost as a function of an observable and an unobservable component,

$\ln \left(m c_{j}\right)=W_{j} \gamma+\omega_{j}$

where $m c_{j}$ is the marginal cost for car model $j, W_{j}$ and $\omega_{j}$ are observed and unobserved car characteristics respectively, and $\gamma$ is a parameter vector to be estimated. This equation yields an indirect approach for calculating a hedonic-cost equation for heterogeneous products and incorporates the fact that changes in characteristics affect marginal cost. 


\section{Econometric issues}

As with demand models of homogeneous products, the main issue that arises in models of differentiated products is that prices are likely to be correlated with the error term generating biased coefficients under OLS estimation. This correlation arises as a result of the existence of unobserved characteristics which affect demand, but are also correlated with prices. ${ }^{11}$ As pointed out by Berry, Levinsohn And Pakes (1995) and Nevo (1999), although unobserved car characteristics are not directly observed, they are observed by producers and taken into account when maximising profits. Additionally, due to the Nash-Bertrand specification, market shares and prices are simultaneously determined in equilibrium, generating endogeneity for shares as well.

The solution to this problem is the use of instrumental variables. Our identification condition uses variables which are correlated with price and shares, but not correlated with the error term. Based on the oligopolistic structure of the model, Berry, Levinsohn and Pakes (1995) propose instruments which are functions of characteristics and cost shifters. The variables constructed from functions of exogenous characteristics act as proxies for the intensity of competition faced by firms. For each characteristic used to explain the demand for car model $j$, three instruments are used: the characteristic of car $j$, the sum of the characteristic across cars other than $j$ produced by firm $f$, and the sum of characteristics of competing cars produced by rival firms. Additionally, the number of car models sold by own-firms in a group and the number of car models sold by rival firms in the group are also used as instruments. We expect that the greater the number of products a particular firm sells, the higher the price it will charge for each product (Goldberg and Verboven, 1999).

Unlike other studies which apply the same methodology, our interest is on the demand side of the model. Therefore, although the demand and pricing equations could be estimated simultaneously as a system using GMM, we opted for estimating the demand side parameters only. Since our interest is in obtaining consistent estimates for the demand side parameters, it is sufficient to model for prices and shares, without a need to model explicitly for supply (Fershtman and Gandal,1998). ${ }^{12}$ The supply side is then introduced into the model in order to calculate mark-ups and marginal costs for 1997. Furthermore, in order to simulate new equilibrium for price and quantities we use the pricing equation together with the demand share equation. ${ }^{13}$

Finally, it is important to note that the structure of our data means that several car models appear in different years. However, since few models have repeated observations, some of them appearing only once from 1993 to 1997, we opted not to undertake an unbalanced panel estimation. Instead, we estimated the model as a cross section, adopting dummies for each

\footnotetext{
${ }^{11}$ Unobserved car characteristics such as style, prestige and reputation as noted by Berry, Levinsohn and Pakes (1995) and quality of the product, reliability, reputation as observed by Goldberg (1995).

${ }_{12}$ As pointed out by Goldberg and Verboven (1998), efficiency loss results from such an approach.

${ }^{13}$ For a further analysis of the supply side and mark-ups for Brazil see Fiuza (2000).
} 
time period. This approach is likely to yield consistent but not efficient estimates of elasticity parameters (Berry, Levinsohn and Pakes, 1995, pp. 863). 


\section{Data and Econometric Results}

\section{Data}

The dataset used in this paper was assembled at IPEA and merges information on prices and sales with characteristics of each car model sold in the Brazilian market from 1993 to 1997, and pollution emissions data from 1992 to 1997. The dataset focuses on the market for passenger cars, thus excluding trucks, vans, minivans and SUVs (all of these car models had very low shares in the Brazilian car market prior to 1998). Monthly sales data were collected from Sindipeças, the Brazilian association of part and component manufacturers; Anfavea, the national association of motor vehicle manufacturers; and Abeiva, the association of automobile importers. Additional import data were provided by individual manufacturers. Monthly data were then aggregated into annual values. The beginning of each model year was October of the previous year, when the domestic manufacturers began selling their new models. Car sales were then totalled over the respective months.

Prices were obtained from the Brazilian monthly magazines Quatro Rodas and AutoEsporte. Like Berry, Levinsohn and Pakes (1995), we used the retail price list which was then converted into the same currency and deflated by the General Price Index (IGP-OG). The base model was used to link price, characteristics and sales. In order to transform monthly prices into annual values, we used averages over the annual period for prices and tax/tariff rates.

Automobile characteristics were obtained from Jornal do Carro and complemented by importers' information and by Quatro Rodas magazine. Data on characteristics include number of doors, engine size, horsepower, air conditioning, power windows, power brakes amongst others. Following Berry, Levinsohn and Pakes (1995), we also aggregated car submodels into a single model. In order to transform monthly characteristics of different submodels into annual characteristics for the base model, we used the mode of characteristics (weighted by sales across months) over the period. ${ }^{14}$

Fuel consumption information and pollution emissions data were provided by Cetesb, the São Paulo state environmental agency. The data are derived for the tests undertaken by Cetesb under the National Programme for Vehicle Pollution Control (Proconve). Data on pollution emissions were collected for CO, HC and NOx for all cars tested between 1992 and 1997.

In Table 1 we present a summary of the 1997 data aggregated by car categories and nationality. We observe that popular cars have by far the largest share in the market with approximately 54\%. The average price for popular cars is significantly lower than other car models. Imported cars represent only $5 \%$ of total car sales. This is mainly due to the fact that the most expensive cars belong in this category with very few imported compact models being sold at competitive prices. Although the popular car category has the largest market share, it has only seven car models. In terms of pollution emissions of $\mathrm{HC}$, the dirtiest cars belong, on average, to the domestic medium and luxury categories, followed by the popular and imported luxury categories. However, since luxury cars have such a small market share, the main

${ }^{14}$ For a more detailed description of the dataset see Fiuza (2000). 
contributors to total emissions are popular and domestic medium cars, which are responsible for approximately $75 \%$ of total emissions (emission rate times quantity sold).

Table 1: Summary statistics for the 1997 car market by category

\begin{tabular}{lcccccc}
\hline $\begin{array}{l}\text { Automobile } \\
\text { Category }\end{array}$ & $\begin{array}{c}\text { Number of } \\
\text { car models in } \\
\text { category }\end{array}$ & $\begin{array}{c}\text { Total car } \\
\text { sales }\end{array}$ & $\begin{array}{c}\text { Share of total } \\
\text { sales }(\%)\end{array}$ & $\begin{array}{c}\text { Average price } \\
(1997 \mathrm{R} \$)\end{array}$ & $\begin{array}{c}\text { Average HC } \\
\text { emissions } \\
(\mathrm{g} / \mathrm{km})\end{array}$ & $\begin{array}{c}\text { Share of total } \\
\text { emissions } \\
(\%)\end{array}$ \\
\hline Domestic Popular & 7 & 862,004 & 53.95 & 12,130 & 0.15 & 54.27 \\
Domestic Compact & 11 & 232,608 & 14.56 & 17,246 & 0.11 & 10.75 \\
Domestic Medium & 26 & 247,306 & 15.48 & 18,683 & 0.20 & 20.62 \\
Domestic Large & 13 & 134,801 & 8.44 & 24,430 & 0.12 & 6.82 \\
Domestic Luxury & 4 & 40,380 & 2.53 & 32,139 & 0.20 & 3.44 \\
Imported Compact & 9 & 8,442 & 0.53 & 16,572 & 0.13 & 0.46 \\
Imported Medium & 17 & 34,985 & 2.19 & 23,855 & 0.12 & 1.74 \\
Imported Large & 26 & 29,348 & 1.84 & 34,246 & 0.11 & 1.41 \\
Imported Luxury & 13 & 7,866 & 0.49 & 54,596 & 0.15 & 0.48
\end{tabular}

Note: Average prices and emissions are weighted by sales. Total emissions do not take into consideration miles driven.

\section{Results for the estimated nested-logit model}

The discrete-choice model specified by equation (4) is estimated using instrumental variables. The net share of car model $j$ is explained as a function of price, characteristics, the shares of car $j$ in the sub-group and the share of the sub-group in the group, with four dummy variables for classes popular, medium, large and luxury (the compact class being omitted). Additionally, we include a dummy variable for ethanol cars, dummies for years having 1993 as the base year, and for imported cars which are iterated with year dummies capturing the change in the pattern of imported cars over time (this dummy is likely to capture the effect of the exchange rate on the demand for imported cars as well).

The endogenous variables price and shares, which are likely to be correlated with the error term, use similar instruments to those used in Berry, Levinsohn And Pakes, Verboven and Goldberg (1998) and Fershtman et al (1999): the sums of characteristics in the groups and outside the groups, the number of cars in the groups and the number of car models outside the groups.

Table 2 reports on the results of the IV nested-logit model. The results obtained are highly satisfactory. The coefficients on horsepower, air, size and power brakes are statistically significant and have the expected positive sign. They suggest that, controlling for other variables, consumers prefer larger cars with better acceleration, air conditioning and with power brakes. The coefficient on kilometres per litre, although significant, has a negative sign as in the result obtained by Berry, Levinsohn And Pakes (1995). This could be due to the presence of imported cars, which have low sales, but have very high fuel efficiency. 
Table 2: Demand estimation of the nested-logit model Dependent variable: Ln (share of car $\boldsymbol{j}$ - share of outside alternative)

\begin{tabular}{lcc}
\hline Variable & Parameter Estimate & Standard Error \\
\hline Constant & 7.964 & 3.261 \\
Ln (Price) & -1.381 & 0.368 \\
Ln (share sub-group) & 0.491 & 0.121 \\
Ln (share group) & 0.802 & 0.054 \\
Horsepower/Weight & 7.415 & 2.564 \\
Standard of air & 0.240 & 0.072 \\
Conditioning & & \\
Size & 0.095 & 0.047 \\
Power Brakes & 0.229 & 0.062 \\
Km per litre & -0.030 & 0.011 \\
Ethanol & -0.533 & 0.124 \\
Popular & 0.757 & 0.212 \\
Medium & 0.577 & 0.092 \\
Large & 0.095 & 0.104 \\
Luxury & -0.631 & 0.180 \\
Year 94 & 0.040 & 0.051 \\
Year 95 & -0.151 & 0.103 \\
Year 96 & -0.385 & 0.134 \\
Year 97 & -0.237 & 0.157 \\
Imported 93 & -1.307 & 0.487 \\
Imported 94 & -1.113 & 0.355 \\
Imported 95 & -0.655 & 0.224 \\
Imported 96 & -0.765 & 0.294 \\
Imported 97 & -0.853 & 0.277 \\
\hline Note: Robust standard
\end{tabular}

Note: Robust standard errors are reported. Data used in the estimation: 1993-1997 with 720 observations.

The set of dummies included aims to capture additional characteristics. Although the large dummy is not significant, the popular and medium dummies are significant with positive signs indicating larger sales with respect to compact cars. The luxury car dummy is also significant with the expected negative sign. The ethanol dummy indicates that ethanol cars have lower sales than gasoline cars. Year dummies alone, which try to control for macroeconomic shocks, are not significant in general, except for 1996. On the other hand, imported dummies multiplied by year dummies are highly significant for all years. This result may indicate that yearly macroeconomic shocks had a greater effect on imported cars than on domestically produced cars.

The variables share of group and share of sub-group are highly significant and have coefficients with values of 0.49 and 0.80 respectively. They indicate a high substitution pattern among models in the same sub-group (small, medium, large and luxury) and a lower substitution pattern among models in the same group (national and foreign cars). This result is consistent with our expectations and also with results obtained in other studies such as Goldberg and Verboven (1998). The hypothesis of equality between these two coefficients is rejected and the results are consistent with MacFadden's conditions for compatibility of the nested-logit model with a random utility model. The reverse order nested-logit model was also estimated assuming that the consumer chooses the type of car first and then the nationality, but results were not satisfactory. 
Table 3: Average price elasticities by car category

\begin{tabular}{lc}
\hline Automobile category & $\begin{array}{c}\text { Average } \\
\text { Elasticity }\end{array}$ \\
\hline Domestic Popular & -5.78 \\
Domestic Compact & -5.38 \\
Domestic Medium & -6.28 \\
Domestic Large & -5.39 \\
Domestic Luxury & -5.38 \\
Imported Compact & -5.54 \\
Imported Medium & -6.09 \\
Imported Large & -6.50 \\
Imported Luxury & -6.32 \\
\hline
\end{tabular}

Note: Average elasticities are weighted by sales.

The coefficient on price is also highly significant, with the expected negative sign. The magnitude of the coefficient is better appreciated by calculating price elasticities. A summary of average elasticities by car category is presented in Table 3. The average own-price elasticity, weighted by sales, is approximately -5.77 and the unweighted average price elasticity is -6.6 . These values are consistent with elasticities obtained by similar nested-logit models. Goldberg and Verboven (1999) estimated average price elasticities for the European car market to vary between -4.09 (for Italy) and -6.21 (for UK). Goldberg (1995) estimated average price elasticities for the US car market to vary between -2.59 and -6.22 . In general the model implies similar results obtained by previous work by Berry, Levinsohn and Pakes (1995), Goldberg (1995) and Goldberg and Verboven (1999): crowded categories have larger price elasticities than uncrowded categories.

\section{Results for the estimated hedonic marginal cost}

Using the estimated elasticities and the observed prices and market shares, we compute markups and marginal costs. A hedonic marginal cost equation is then estimated based on equation (8) where the log of marginal cost is regressed on a set of characteristics, a set of dummies and car sales in order to control for economies of scale. This estimation is undertaken using a cross-section of 1997 data. This restriction is imposed since we are interested in estimating the effect of emission changes on marginal cost given the ultimate available technology. ${ }^{15} \mathrm{We}$ include all automobile characteristics and pollution emissions of $\mathrm{HC}$ in grammes per $\mathrm{km}$. Controlling for other characteristics, the coefficient on $\mathrm{HC}$ estimates the change in marginal cost caused by a marginal reduction of pollution emissions. ${ }^{16}$

The results of the hedonic marginal cost estimation are presented in Table 4. The fit of the model indicates that a linear function with the chosen characteristics can account for most of the cross-section differences in marginal costs across car models. All the coefficients have the

\footnotetext{
${ }^{15}$ The cars which were not in compliance with the Proconve regulation (they were allowed to be sold until March 1997) were taken out of the sample.

${ }^{16}$ Our approach differs from Berry, Kortum and Pakes (1996). Instead of using dummies for the technological equipment introduced, we use actual emissions data in order to estimate the effect of different emission levels on marginal cost.
} 
expected sign and are significant at the 5\% level, except for air conditioning, engine size and the dummy for popular cars.

As expected, the presence of air conditioning, power brakes, power windows, acceleration (measured by hp/weight), engine size and tank size increases marginal cost. Medium, large and luxury cars have higher marginal costs than compact cars, controlling for other included characteristics. Additionally, we find that ethanol and imported cars are produced with lower marginal costs. The significant negative coefficient for sales points to increasing returns to scale (although the presence of fixed costs already allows for IRS even in the presence of constant marginal costs). However, it is important to note that sales are a good proxy for national production, but a poor proxy for the output of imported cars. Therefore, the effect of returns of scale may be underestimated.

The coefficient of the log of $\mathrm{HC}$, which is used for simulation purposes, is precisely estimated with the expected negative sign (decreasing pollution implies higher marginal cost). The parameter value indicates that a decrease in $1 \%$ in emissions of $\mathrm{CO}$ would result, on average, in an increase of $0.121 \%$ in the marginal cost. This coefficient is used as the marginal cost of pollution control for the average predominant technology (given by the type of fuel injection and the type of catalytic converter). ${ }^{17}$

Table 4: Parameter estimates for the hedonic marginal cost

Dependent variable: Ln (Marginal Cost)

\begin{tabular}{lcc}
\hline Variable & Parameter Estimate & Standard Error \\
\hline Constant & 8.68 & 0.456 \\
Ln (HC) & -0.121 & 0.029 \\
Ln (horsepower/weight) & 0.515 & 0.100 \\
Ln (tank) & 0.422 & 0.093 \\
Air conditioning & 0.112 & 0.039 \\
Power Window & 0.090 & 0.034 \\
Power Brake & 0.172 & 0.040 \\
Popular & 0.099 & 0.063 \\
Medium & 0.112 & 0.028 \\
Large & 0.172 & 0.042 \\
Luxury & 0.374 & 0.058 \\
Ethanol & -0.189 & 0.046 \\
Imported & -0.100 & 0.043 \\
Ln (sales) & -0.026 & 0.009 \\
$R^{2}$ & & \\
\hline
\end{tabular}

Note: Robust standard errors. Data is for 1997 based on 114 observations.

\footnotetext{
${ }^{17}$ The hedonic marginal cost was also estimated with the instrumental variables used in the demand estimation in order to control for the possible endogeneity of sales. Nevertheless, neither the coefficient nor the standard error on the $\mathrm{HC}$ emission was significantly different from the result obtained with the OLS estimation. Therefore, we opted for including only the OLS result.
} 


\section{Simulating the Effect of Environmental Regulation}

The parameters estimated in the demand and marginal cost regressions are used together with the calculated elasticities, the share and pricing equations, the tax rate schedule and the pollution emissions coefficients to simulate the effect of government policies on the equilibrium quantity, price, pollution emissions and tax revenue.

Total pollution emissions for each car model are determined by the emissions coefficient (emissions per kilometre) multiplied by the number of kilometres driven in a given year multiplied by the number of cars sold. Since we do not have data on kilometres driven, we calculate total emissions by kilometre and base our analysis on the composition of the car fleet.

Aggregate emissions generated by new cars sold are then defined as the sum of the emissions generated by each car model per kilometre multiplied by the number of cars sold,

$$
E=\sum_{j=1}^{J} q_{j} e_{j}
$$

where $q_{j}$ is the quantity sold of automobile model $j, e_{j}$ is the emission rate in grammes per kilometre of automobile type $j$ and $J$ is the total number of car models sold in the market.

The counterfactual simulation uses data on the 126 car types being sold in 1997. The model consists of 126 demand side equations given by (3) and 126 pricing equations given by (7). Introducing a change in the marginal cost of manufacturers, we obtain a new Bertrand-Nash equilibrium with new quantities and new prices by solving the 252 non-linear equation system.

The environmental regulation is introduced in the model with the simulation of a new environmental standard. Instead of the prevailing emission standard for $\mathrm{HC}-$ which was equal to $0.3 \mathrm{~g} / \mathrm{km}$ in 1997 - we simulate the introduction of an emission standard of $0.15 \mathrm{~g} / \mathrm{km}$. This standard was chosen as representing a 50\% reduction in the maximum amount of HC allowed for each automobile. It is noteworthy that several car models already had an emission level below 0.15 in 1997 . These models are considered to be in compliance with the assumed new standard.

The effect of this new environmental standard in the market is simulated in two steps. First, we observe which cars had emission levels above $0.15 \mathrm{~g} / \mathrm{km}$ in 1997 . We assume that manufacturers, in order to be able to sell cars, would have to introduce new technology incurring an additional marginal cost. For each car model we calculated how much the reduction in $\mathrm{HC}$ would have to be in order to comply with the new regulation. For car models with emissions above 0.15 , we assume that such investments generate perfect compliance with a binding standard. ${ }^{18}$ Assuming that all car models have, on average (after controlling for

\footnotetext{
${ }^{18}$ In other words, we assume their emission coefficient is equal to $0.15 \mathrm{~g} / \mathrm{km}$. Although this is a bold assumption, it is used to illustrate the compliance pattern and the effect of a higher marginal cost for each manufacturer.
} 
other characteristics), the same pattern of marginal cost of pollution control, we use the estimated coefficient on $\mathrm{HC}$ from Table 3 and calculate the additional marginal cost borne by each car model in order to attain the new emission standard. We then introduce this cost of compliance into each manufacturer's profit function and let them adjust their prices and markups.

If producers were not allowed to adjust their prices, the total emissions from new automobiles would be given by the quantity sold prior to the standard implementation multiplied by the new emission rate per vehicle. However, the oligopolistic feature of the model allows each firm to set a new price and mark-up after we introduce a marginal cost of environmental compliance. The model allows us to calculate the final price/quantity equilibrium once a new Bertrand-Nash equilibrium is reached. Taking the new equilibrium for quantities sold of each car model, we compute total emissions resulting from the new standard and total tax revenue.

\section{The effects of a new environmental standard}

Based on data from 1997, we undertake the counterfactual simulation of a new environmental standard for automobile emissions of HC. We attempt to answer the following question: what would have happened to sales, prices, tax revenues and total emissions if the government had defined an environmental standard for HC emissions of $0.15 \mathrm{~g} / \mathrm{km}$ instead of $0.30 \mathrm{~g} / \mathrm{km}$ in 1997. This simulation is closely related to those of Berry, Levinsohn and Pakes (1998); Goldberg (1998) and Petrin (2000).

The results obtained from the simulation of the new environmental standard are summarised in Table 5 and Table 6 . The aggregate effect of this is the expected increase in price and reduction in total car sales. Average price increases by $12 \%$ and total car sales decrease by $31 \%$. This results in a loss in government revenue from taxes of approximately $17 \%$. On the other hand, since emissions of most pollutant cars are controlled and driven down to a maximum of $0.15 \mathrm{~g} / \mathrm{km}$, total emissions are reduced by approximately $40 \%$. This is mainly due to the reduction in the demand for automobiles driven by the price increase. Although the fleet composition changes towards a cleaner profile, weighted average emissions of HC decrease from 0.15 to $0.13 \mathrm{~g} / \mathrm{km}$.

Table 5: Aggregate effect on prices, sales, tax revenue and total emissions from the implementation of a new standard for hydrocarbon emissions

\begin{tabular}{lllll}
\hline & $\begin{array}{l}\text { Average price } \\
(\mathrm{R} \$)\end{array}$ & $\begin{array}{l}\text { Total car sales } \\
(1000 \text { car units })\end{array}$ & $\begin{array}{l}\text { Total tax revenue } \\
(\mathrm{R} \$ 1000)\end{array}$ & $\begin{array}{l}\text { Total HC emissions } \\
(\mathrm{g} / \mathrm{km})\end{array}$ \\
\hline $\begin{array}{l}\text { Baseline 1997 } \\
\begin{array}{l}\text { Environmental standard } \\
\text { Simulated new evironmental }\end{array}\end{array}$ & 16,328 & $1,597.7$ & $7,890,614.4$ & 238,174 \\
$\begin{array}{l}\text { standard } \\
\text { Percentage change }\end{array}$ & 18,407 & $1,101.4$ & $6,571,843.7$ & 144,845 \\
\hline
\end{tabular}

Note: average price is weighted by sales. Total emissions are calculated for kilometre and do not take into account different distances in kilometres driven. 
The effects of the new regulation on individual car models and categories are more complicated. Once marginal cost of pollution control is introduced, the price of cars can change disproportionally due to the Bertrand game structure. As mentioned in Berry, Levinsohn and Pakes (1998), the issue of strategic complements and substitutes is important in order to understand the final results of the simulation. Since we are using non-linear demands, an increase in the price of a car does not necessarily increase the price of the competing car as it would occur in a Bertrand game with linear demands. Therefore, once the price of a polluting car increases, it is possible that rivals reduce the price of the competing car in order to attract more price-sensitive consumers and increase profits.

The results are aggregated by car category and summarised in Table 6 . They seem to suggest that car models which had the highest emission rates and had to comply with the new regulation also had the largest price increases. The car categories that have the greatest effect on marginal cost of compliance are domestic large, luxury and medium cars with a marginal cost increase of $2.2 \%, 2.3 \%$ and $3.1 \%$ respectively. Prices increase in all of these three categories, the highest increase being in the domestic medium category, with an increase of $7.8 \%$. Imported compact cars also have a substantial price increase of $6 \%$, but this is not likely to be driven by marginal cost changes but by increase in demand. In terms of market share, imported cars gain a substantial portion of the market lost by domestic popular and compact cars.

Table 6: Percentage change in price, market share, sales, tax revenue and total emissions from the implementation of a new standard for hydrocarbon emissions

\begin{tabular}{|c|c|c|c|c|c|}
\hline Automobile Category & Price & Market share & Sales & Tax Revenue & Total HC emissions \\
\hline Domestic Popular & $-1,3 \%$ & $-34.5 \%$ & $-54.8 \%$ & $-55.4 \%$ & $-60.5 \%$ \\
\hline Domestic Compact & $-2.6 \%$ & $-9.4 \%$ & $-37.6 \%$ & $-39.0 \%$ & $-34.2 \%$ \\
\hline Domestic Medium & $+7.8 \%$ & $+68.6 \%$ & $+16.2 \%$ & $+25.4 \%$ & $-16.7 \%$ \\
\hline Domestic Large & $+1.3 \%$ & $+43.7 \%$ & $-0.9 \%$ & $+4.1 \%$ & $+3.4 \%$ \\
\hline Domestic Luxury & $+3.1 \%$ & $+58.8 \%$ & $+9.5 \%$ & $+12.9 \%$ & $-21.0 \%$ \\
\hline Imported Compact & $+6.3 \%$ & $+304.0 \%$ & $+178.9 \%$ & $+197.8 \%$ & $+164.6 \%$ \\
\hline Imported Medium & $-16.0 \%$ & $+75.3 \%$ & $+20.9 \%$ & $+0.1 \%$ & $+35.7 \%$ \\
\hline Imported Large & $-4.0 \%$ & $+33.0 \%$ & $-8.3 \%$ & $-15.9 \%$ & $-10.0 \%$ \\
\hline Imported Luxury & $-4.8 \%$ & $+66.6 \%$ & $+14.9 \%$ & $+7.7 \%$ & $+7.0 \%$ \\
\hline
\end{tabular}

Note: changes in emissions are in $\mathrm{g} / \mathrm{km}$ and assume that all drivers are homogeneous and drive the same number of kilometres.

If we believe that larger and more expensive cars are driven by richer consumers who tend to drive more miles, the results suggest that, although we reduce total emissions per kilometre by reducing the total number of cars sold and by changing the fleet profile, we could be increasing total emissions by shifting the fleet towards less fuel-efficient models which would be driven by richer consumers. However, we are unable to analyse these types of effect due to the lack of consumer specific data. Furthermore, it is important to note that the model used here can only simulate policy changes in the short-term, since we have to assume that characteristics of the cars marketed do not change in response to the policy implemented 
(Pakes, Levinsohn and Berry, 1993). ${ }^{19}$ Therefore, one important benefit of the environmental regulation - innovation - cannot be analysed within the present framework.

The welfare effects of the simulated regulatory policy are ambiguous and will need further research. Although the government loses approximately $40 \%$ in tax revenue and consumers and firms are worse off due to higher prices and profit losses, there are welfare gains associated with pollution reductions. Therefore, the cost-benefit analysis of the regulatory policy can only be achieved if we calculate the social benefit of such a reduction. Although we do not undertake such a task in this paper, this could be done in future research using estimates of social costs of automobile pollution. ${ }^{20}$

${ }^{19}$ This is also the assumption used by Goldberg (1998) in her analysis of the effect of CAFE regulation in the US.

${ }^{20}$ See Small and Kazimi (1995). 


\section{Concluding remarks}

Environmental regulation in the Brazilian automobile market has resulted in important technological changes, with the rapid adoption of fuel injection and catalytic converters. Although a substantial reduction in pollution emissions occurred from 1988 to 1997, the task of environmental control of vehicle pollution emissions is far from complete. We focused the discussion on the control of new car pollution emissions, although other mechanisms such as inspection and maintenance programmes, and fleet turnover programmes, are needed to control total pollution emissions. ${ }^{21}$

In a discussion of further environmental regulation for new cars, it is important to estimate the effect of such regulation on the market. Automobile production costs, prices and, consequently, tax revenues are likely to be affected by government regulation. In order to undertake such a discussion, an adequate model which can predict the effect of cost changes on prices and quantities sold, taking into account the oligopolistic feature of a differentiated product market, is needed. Parameters estimated by the present paper could then be used for undertaking a cost-benefit analysis of environmental regulation.

This paper contributes to the existing literature by estimating such a model and linking it to the environmental policy discussion. First, we applied the nested-logit model to the Brazilian car market in order to obtain demand price elasticities which are consistent with a random utility framework with heterogeneous consumers. Second, using the estimated marginal costs, we estimated a hedonic marginal cost function in order to describe the relationship between marginal costs and automobile characteristics, including emissions control equipment. Third, using a system of non-linear demand and pricing equations, we simulated the effect of an environmental policy in order to illustrate the model. The oligopolistic structure of the market is found to be important. The pattern of price and demand changes, permitted by the use of a non-linear demand function, imply a more realistic pattern of substitution between car models. Therefore, the effect of the regulation is simulated with greater precision.

The elasticities estimated by the model are found to be close to elasticities obtained by similar models using data from the US and European countries. Applying the estimated elasticities together with the marginal cost elasticity with respect to emissions control, we find that the introduction of further environmental regulation is likely to increase prices and reduce sales, as expected. The increase of $12 \%$ on the average price reduces total sales by $=$. Tax revenues decrease by $17 \%$ as a consequence of the new regulation, but tota emissions decrease by $40 \%$. Therefore, we conclude that although only half of the cars being sold in 1997 are obliged to reduce emissions (the other half already had an emissions rate below $0.15 \mathrm{~g} / \mathrm{km}$ ), substantial reduction is obtained due to additional market effects.

Although the results are quite general and could be used for other types of simulations in the Brazilian car market, it is important to mention some limitations of the model. Due to the

\footnotetext{
${ }^{21}$ See Harrington, McConnell and Alberini (1996) for a discussion of I/M policies and Alberini, Harrington and McConnell (1995) for a discussion of vehicle retirement programmes in the US.
} 
static framework, the model can analyse only short-term implications of government policies. The implementation of new environmental regulations, for example, is likely to result in further innovation and possibly in better cars. This dynamic effect cannot be captured by the present model.

Another point could be made about the use of a nested-logit framework. This model restricts elasticities inside a segment, and the pattern of substitution is pre-determined with the imposition of the segment structure. A more general random coefficients model could be used, introducing not only the general substitution pattern, but the pricing equation in the estimation. Although this is likely to be more realistic in the substitution patterns, the superiority of the predictive power of the random coefficient model over the nested-logit model is not absolutely clear. ${ }^{22}$

Another important point relates to the fact that the results of the model for emissions are analysed in terms of total emissions per kilometre. We know that owners of different cars drive different distances. Therefore, the current version of the model cannot predict actual total emissions. Nevertheless, this estimation could be used for such a purpose if data on income levels and kilometres driven were available.

The final point concerns the instrument adopted in our counterfactual exercise of pollution control. Although most countries adopt vehicle pollution standards for controlling pollution, economists usually prefer market-based instruments due to their greater cost-effectiveness in attaining pollution control, particularly if we believe that emissions control costs are heterogeneous across manufacturers. Nevertheless, a first-best tax which targets emissions directly is hard to implement due to extremely high monitoring and transaction costs. An alternative policy would be to modify the current tax structure in order to create incentives for cleaner car sales. The model developed here could be applied for estimating the effects of such a taxation scheme.

${ }^{22}$ See Wojcik (2000) for a comparison of the results from both models for the US automobile market. 


\section{Bibliography}

Alberini, A., Harrington, W. and McConnell, V. (1995), "Determinants of participation in vehicleretirement programs", Rand Journal of Economics 26 (1): 93-112.

Anfavea (1999), Brazilian Automotive Industry Statistical Yearbook, São Paulo: Anfavea.

Berry, S. (1994), "Estimating discrete choice models of product differentiation", Rand Journal of Economics 25(2).

Berry, S., Kortum, S. and Pakes, A. (1996), "Environmental change and hedonic cost functions for automobiles", Proceedings of the National Academy of Sciences Vol 93: 12731-12738.

Berry, S., Levinsohn, J., and Pakes, A. (1995), “Automobile prices in market equilibrium", Econometrica 63 (4): 841-890.

Berry, S., Levinsohn, J., and Pakes, A. (1998), "Voluntary export restraints on automobiles: evaluating a trade policy", American Economic Review.

CETESB (1998), Relatório de qualidade do ar no estado de São Paulo: 1997. Série Relatóri,: São Paulo: CETESB.

Eskeland, G.S. (1994), “A presumptive pigovian tax: complementing regulation to mimic an emission fee", The World Bank Economic Review 8(3).

Ferraz, C. and Seroa da Motta, R. (2000), The pattern of compliance to environmental regulation: evidence from the automobile industry, Mimeo, Rio de Janeiro: IPEA.

Fershtman, C. and Gandal, N. (1998), "The effect of the Arab boycott on Israel: the automobile market” Rand Journal of Economics 29 (1): 193-214.

Fershtman, C., Gandal, N. and Markovich, S. (1999), "Estimating the effect of tax reform in differentiated product oligopolistic markets" Journal of Public Economics Vol 74.

Fiuza, E.P.S. (2000), Automobile demand and supply in Brazil, Mimeo, Rio de Janeiro: IPEA.

Fullerton, D. and West, S. (2000), Tax and subsidy combinations for the control of car pollution, NBER Working paper 7774, Cambridge MA: National Bureau of Economic Research.

Gaseta Mercantil (1999), "Montadoras reforçam o marketing da segmentação", Gaseta Mercantil, 9 September.

Goldberg, P.K. (1995), "Product differentiation and oligopoly in international markets: the case of the US automobile industry", Econometrica 63 (4): 891-951.

Goldberg, P.K. (1998), "The effects of the corporate average fuel efficiency standards in the US", The Journal of Industrial Economics XLVI (1): 1-33.

Goldberg and Verboven (1998), The evolution of price discrimination in the European car market, NBER Working Paper 6818, Cambridge MA: National Bureau of Economic Research. 
Harrington, W., McConnell, V. and Alberini, A. (1996), Economic incentive policies under uncertainty: the case of vehicle emission fees, Resources for a Future Discussion Paper 96-32, Washington DC: Resources for the Future.

Innes, R. (1996), "Regulating automobile pollution under certainty, competition and imperfect information", Journal of Environmental Economics and Management 31(2).

Johnstone, N. and Karousakis, K. (1998), "Economic incentive policies to reduce pollution emissions from transport: the case for vehicle characteristics taxes", Transport Policy 6 (1999): 99-108.

Pakes, A., Berry, S. and Levinsohn, J. (1993), "Applications and limitations of some recent advances in empirical industrial organization: price indexes and the analysis of environmental change", American Economic Review Papers and Proceedings, May 1993.

Petrin, A. (1999), Quantifying the benefits of new products: the case of the minivan. Mimeo, University of Chicago. Available at http://gsbwww.uchicago.edu/fac/amil.petrin.

Sevigny, M. (1998), Taxing Automobile Emissions for Pollution Control, Cheltenham: Edward Elgar.

Small, K. and Kazimi, C. (1995) "On the costs of air pollution from motor vehicles", Journal of Transport Economics and Policy Vol 29, January.

Verboven, F. (1996), "International price discrimination in the European car market", Rand Journal of Economics 27(2): 240-268.

Wojcik, C. (2000), “Alternative models of demand for automobiles”, Economic Letters 68: 113-118. 


\section{PUBLICATIONS AND ORDERING DETAILS}

The following papers are available for purchase from Earthprint Limited at the address below. Northernbased readers are charged $£ 12.00$ or US\$18 per paper, plus postage and packing. For our Southern readers, hard copies are available free of charge, although larger quantities (more than 6) will incur postal costs. All papers may be downloaded free in PDF format from the CREED website, at www.iied.org/creed. Requests for free papers should be made to Frances Reynolds, Environmental Economics Programme, International Institute for Environment and Development, 3 Endsleigh Street, London WC1H 0DD, or email your requests to frances.Reynolds@iied.org

\section{CREED Working Paper Series.}

No 1. Adjustment policies and the environment: a critical review of the literature. Carlos E.F. Young and Joshua Bishop. July 1995.

No 2. Environmental regulations as trade barriers for developing countries: eco-labelling and the Dutch cut flower industry. Harmen Verbruggen, Onno Kuik \& Martijn Bennis. July 1995.

No 3. Economic incentives for watershed protection: a report on an ongoing study of Arenal, Costa Rica. Bruce Aylward, Jaime Echeverría \& Edward B. Barbier. September 1995.

No 4. Economic policies for sustainable water use in Thailand. Ritu Kumar and Carlos Young. June 1996.

No 5. The informal sector and waste paper recovery in Bombay. Pieter van Beukering, Edwin Schoon and Ajit Mani. June 1996.

No 6. Economic trends in the timber industry of the Brazilian Amazon: evidence from Paragominas. Steven Stone. July 1996.

No 7. Input substitution in the Indian paper industry: a variable cost function approach. K.V. Ramaswamy, R.R. Vaidya, M.J. Bennis and J.G.M. Hoogeveen. July 1996.

No 8. Poverty and environmental degradation: a literature review and analysis. Anantha K. Duraiappah. October 1996.

No 9. Valuation and evaluation of management alternatives for the Pagbilao Mangrove Forest. Ron Janssen and Jose E Padilla. October 1996.

No 10. The economic and environmental impacts of the waste paper trade and recycling in India: a material balance approach. Pieter van Beukering and Anantha K. Duraiappah. November 1996.

No 11. Incentives for eco-efficiency: lessons from an evaluation of policy alternatives; a case study of the steel sector in India. Ritu Kumar, Nick Robins, A.K. Chaturvedi, R. Srinivasan and J. Gupta. December 1996. 
No 12. Poverty and environment linkages in mountains and uplands: reflections on the 'poverty trap' thesis. Sanjeev Prakash. February 1997.

No 13. The economic importance of wild resources in the Hadejia-Nguru Wetlands, Nigeria. Derek Eaton and Marie-Thérèse Sarch. May 1997.

No 14. Economic valuation of mangrove ecosystems: potential and limitations. Frank Spaninks and Pieter van Beukering. July 1997.

No 15. The use of environmental functions to evaluate management strategies for the Pagbilao Mangrove Forest. Alison J. Gilbert and Ron Janssen. August 1997.

No 16 Trends and issues in the plastics cycle in China, with special emphasis on trade and recycling. Pieter van Beukering, Li Yongjiang, Zhao Yumin \& Zhou Xin. December 1997.

No 17. Economic valuation of communal rangelands in Botswana: a case study. Jaap Arntzen. February 1998.

No 18. Environmental product measures: barriers for South-North trade? Harmen Verbruggen, Onno Kuik, Martijn Bennis, Hans Hoogeveen, Roland Mollerus. March 1998.

No 19. The shrimp aquaculture sector in Thailand: a review of economic, environmental and trade issues. Direk Patmasiriwat, Onno Kuik and Sunil Pednekar. October 1998.

No 20. An analysis of private and social discount rates in Costa Rica. Bruce Aylward and Ina Porras. December 1998.

No 21. Institutional arrangements for watershed management: a case study of Arenal, Costa Rica. Bruce Aylward and Alvaro Fernandez Gonzalez. December 1998.

No 22. Farmers' perceptions and sustainable land use in the Atacora, Benin. A. Adegbidi, K. Burger, E. Gandonou and I. Mulder. February 1999.

No 23. Sustainable livestock management in the Kalahari: an Optimal Livestock Rangeland Model (OLRM). Anantha K. Duraiappah and Jeremy S. Perkins. March 1999.

No 24. Analysing urban solid waste in developing countries: a perspective on Bangalore, India. Pieter van Beukering, Madhushree Sekher, Reyer Gerlagh and Vijay Kumar. March 1999.

No 25. Market and policy incentives for livestock production and watershed protection in Arenal, Costa Rica. Bruce Aylward, Jaime Echeverría, Katherine Allen, Ronald Mejías and Ina T. Porras. March 1999.

No 26. Integrated modelling of solid waste in India. Reyer Gerlagh, Pieter van Beukering, Madhu Verma, P.P. Yadav and Preety Pandey. March 1999.

No 27. The plastics sector in China: issues in production, recycling and international trade. Anantha K. Duraiappah, Zhou Xin and Pieter van Beukering. March 1999.

No 28. Farmers' perceptions of soil fertility in Benin Ingrid Mulder. February 2000. 
No 29. Automobile pollution control in Brazil. Claudio Ferraz and Ronaldo Seroa da Motta. June 2000.

No 30. Soil fertility: QUEFTS and farmers' perceptions. Ingrid Mulder. July 2000.

No 31. Sustainable shrimp farming: estimations of a survival function . Anantha K. Duraiappah, Adis Israngkura and Sombat Sae-Hae. July 2000.

No 32. Traditional Chinese medicine and species endangerment: an economic research agenda. Konrad von Moltke and Frank Spaninks. August 2000.

No 33. Land tenure, land use, environmental degradation and conflict resolution: a PASIR analysis for the Narok District, Kenya. Anantha K. Duraiappah, Gerrishon Ikiara, Mutsembi Manundu, Wilfred Nyangena and Rueben Sinange. August 2000.

No 34. The environmental effects of tax differentiation by vehicle characteristics: results from Costa Rica. Jaime Echeverría, Nick Johnstone, Ronald Mejías and Ina Porras. September 2000.

No 35. Farm permits and optimal shrimp management in Thailand: an integrated intertemporal and spatial planning model. Anantha Kumar Duraiappah and Adis Israngkura. October 2000.

\section{CREED Final Reports}

The following reports are available from recently completed CREED projects. A charge is levied for all readers.

International Trade and Recycling in Developing Countries: The Case of Waste Paper Trade in India. P. van Beukering and V. Sharma (eds). November 1996. 155 pages.

The importance of international trade in the global economy is expanding, not only for primary products but also for recyclable waste. The main objectives of this study were to determine the economic, social and environmental impacts of international trade of waste paper for recycling purposes in India. The report addresses three main sectors: (i) the world market for waste paper, (ii) the local waste paper market and (iii) the Indian paper industry. It also makes recommendations for policy makers at an international, national and local level: international agreements should distinguish between hazardous and non-hazardous waste; national trade barriers to waste imports should be eliminated; and existing local informal recovery sectors should be favoured over formal Western-style recycling systems.

Mangroves or Fishponds? Valuation and Evaluation of Alternative Uses of a Mangrove Forest in the Philippines. Ron Janssen \& Jose Padilla. September 1997. 258 pages.

One of the major threats to mangroves in the Philippines is the rapidly increasing aquaculture industry. This study includes a review of valuation methodologies and their application to the case study area of the Pagbilao experimental mangrove forest in the Philippines. Valuations of goods and services and environmental functions of the forest are employed to assess alternative management regimes using both cost-benefit analysis as well as a multi-criteria 
approach. Much depends on the management objectives: conversion to aquaculture is the most economically efficient management option. However, if equity and sustainability objectives are included, commercial forestry is the preferred alternative.

Incentives for Eco-Efficiency. Market Based Instruments for Pollution Prevention: A Case Study of the Steel Sector. Ritu Kumar, Nick Robins, A.K. Chaturvedi, R. Srinivasan and J. Gupta. December 1997. 96 pages.

Mounting pressures on industry to reduce pollution, to remain globally competitive and to meet the requirements of international standards, require fundamental changes in government policy and corporate approaches to environmental management. This report presents the results of an international study assessing the potential for market-based instruments for pollution prevention in the steel sector in India. It recommends a set of policy measures to reduce discharge levels in the most cost effective manner, to induce firms to adopt cleaner technologies and to encourage firms to economise on energy and water resources. In this regard, the importance of achieving coherence with existing policies, building trust among key stakeholders and gradually phasing in market-based instruments is emphasised.

Economic Incentives for Watershed Protection: A Case Study of Lake Arenal, Costa Rica. Bruce Aylward, Jaime Echeverria, Alvaro Fernandez Gonzalez, Ina Porras, Katherine Allen, Ronald Mejias. February 1998. 323 pages.

Conventional wisdom holds that cutting down tropical forests for livestock production is not only bad business but bad for the environment. In particular, it is thought that conversion of natural forest to pasture leads to a rise in the sedimentation of waterways and resevoirs, increased risk of flooding and loss of dry season water supply. In the case of Lake Arenal, Costa Rica, this conventional view is stood on its head by research showing that ranching, dairy farming and associated downstream hydrological effects represent important positive values to the Costa Rican economy, values that significantly outweigh expected returns from reforestation

Plastics Recycling in China. An International Life Cycle Approach. Edited by Pieter van Beukering. April 1999. 148 pages.

\section{Orders:}
Earthprint Limited
Orders Department
P.O. Box 119
Stevenage
Hertfordshire SG1 4TP
England

Fax: 441438748844

Email: orders@earthprint.co.uk
Enquiries:

Tel: 441438748111

Fax: 441438748844

Email: enquire@earthprint.co.uk 


\section{Shipping Charges:}

Please add payment for postage and packing at the following rates:

\begin{tabular}{|l||l||}
\hline UK & US\$5.00 for the first item plus US\$2.50 for each additional item \\
\hline \hline Europe & US\$6.00 for the first item plus US\$3.00 for each additional item \\
\hline \hline Rest of World & US\$10.00 for the first item plus US\$5.00 for each additional item \\
\hline
\end{tabular}

How to Pay:

Credit card You can pay by VISA, Mastercard, Access or Eurocard. Please include the cardholder address and expiry date.

Cheque Cheques should be in US dollars, drawn against a US bank and made payable to Earthprint Limited. (UK customers can pay in the Sterling equivalent.- conversion rate US\$1.50 $=£ 1.00$

Bank Transfers

Bank transfers should be made to:

The Bank of New York

51 West 51st Street

New York

NY 10019

USA

Account number: 6301545051 